\title{
Breaking the Silence Gulture: Stimulation of Participation and Employee Opinion Withholding Gross-nationally
}

\section{Xu Huang, Evert Van de Vliert and Gerben Van der Vegt}

The Hong Kong Polytechnic University, Hung Hom, Kowloon, University of Groningen and University of Groningen

ABSTRACT We investigated the relationship between the national cultural value of power distance and collective silence as well as the role of voice-inducing mechanisms in breaking the organizational silence. Using data from 421 organizational units of a multinational company in 24 countries, we found that both formalized employee involvement and a participative climate encouraged employees to voice their opinions in countries with a small power distance culture. In large power distance cultures, formalized employee involvement is related to employee voices only under a strong perceived participative climate.

Employees are regarded as major sources of change, creativity, learning, and innovation, which are factors critical to the success of organizations. However, many employees choose not to voice their opinions and concerns about matters in their organizations. Morrison and Milliken (2000) proposed that when most members of an organization choose to keep silent about organizational matters, silence becomes a collective behavior, which is referred to as organizational silence. Organizational silence can have detrimental effects on decision-making and processes of change by blocking alternative views, negative feedback, and accurate information (cf. Bies and Tripp, 1999; Zand, 1972). As many organizations are now operating in a large number of culturally diverse countries, understanding and managing organizational silence cross-nationally would be of interest to both international scholars and international managers.

In his seminal work on cultural dimensions, Hofstede (1991) asserted that, compared to people from countries with a small power distance culture, those from countries with a large power distance culture tend to take hierarchical inequalities for granted and are less likely to voice their concerns to their superiors in order 
to avoid direct conflicts with those in power. Hence, there may be substantial and systematic variations in organizational silence across nations, depending on the degree of power distance in the cultures of those countries where the organizations are located.

At the same time, there is a growing recognition that people's interpretations of and reactions to management practices are shaped by cultural values (e.g., Erez, 1994; Hofstede, 1991). Unlike their counterparts in countries with a small power distance culture, when employees from countries with a large power distance culture were given opportunities to participate in decision-making, they did not become more productive and satisfied with their work (Eylon and Au, 1999; Huang and Van de Vliert, 2003; Robert, Probst, Martocchio, Drasgow and Lawler, 2000). These findings suggest the possibility that management practices aimed at breaking organizational silence may not influence employees to the same extent across nations.

Research evidence suggests that structural and social mechanisms may help encourage employees to voice their concerns about organizational matters. Specifically, employees are more likely to speak up when they are formally involved in activities of decision-making and feedback (cf. Leana, Ahlbrandt, and Murrell, 1992; Marchington, Wilkinson, Ackers, and Goodman, 1994), and when they work in a more open and participative organizational climate (cf. Gorden, Infante, and Graham, 1988; Saunders, Sheppard, Knight, and Roth, 1992). However, the utility of these voice mechanisms across cultures is largely unknown. The current study contributes to the literature by investigating whether there is a systematic link between cultural power distance and organizational silence and by examining whether mechanisms that stimulate employee participation would reduce organizational silence, using a sample of 421 organizational units located in 24 countries in a multinational company.

\section{THEORETICAL BACKGROUND AND HYPOTHESES}

There is an emerging body of research concerned with when and why employees choose to remain silent or to speak up about important organizational issues. Empirical evidence from various sources, such as studies on employee voice (Rusbult, Farrell, Rogers, and Mainous, 1988), issue selling (Ashford, Rothbard, Piderit, and Dutton, 1998), and whistle-blowing (Miceli and Near, 1992), suggests that the decisions of individual employees to speak up can be influenced by individual-level factors such as personality (Premeaux and Bedeian, 2003) and motives (Van Dyne, Ang, and Botero, 2003) as well as by organizational-level factors such as perceived organizational and management support (Edmondson, 2003; Piderit and Ashford, 2003), the perceived risk of speaking up (Milliken, Morrison, and Hewlin, 2003), organizational norms (Bowen and Blackmon, 2003), and institutional norms (Creed, 2003). In addition, research has shown that remaining silent can be an employee's strategy to influence the decisions of supervisors (Creed, 
2003) and that an employee may only choose certain topics about which to speak up while keeping silent on other issues (Milliken et al., 2003; Piderit and Ashford, 2003). The common theme that emerges from these various studies is that withholding opinions is the core element of the silence of individual employees (Van Dyne et al., 2003).

Departing from the above individual-level approach to studies of silence, Morrison and Milliken (2000) proposed that a systematic culture of silence could occur at the organizational level. They defined this organizational-level silence as a collective phenomenon in which employees tend to withhold their opinions and concerns about matters relating to their organizations. Organizational silence may take various forms, such as collective silence in meetings, low levels of participation in suggestion schemes, low levels of collective voice, and so forth. In the current study we focus on only one aspect of silence, the withholding of opinions. This organizational-level silence differs from individual-level silence, employee voice, issue-selling, and whistle-blowing in two ways. First, research on organizational silence focuses on the overall levels of silence in organizations as a collective voice. Second, the primary interest of research on organizational silence is to identify the environmental forces that compel most members in an organization to remain silent (Morrison and Milliken, 2000).

Morrison and Milliken (2000) have noted that national cultural norms may influence the extent to which employees withhold their opinions about their organizations. Since multinational companies tend to have subsidiaries in culturally diverse countries, the level of the organizational silence of their subsidiaries may be shaped by the culture of the host countries, and thus vary substantially and systematically across nations. Research has shown that workers from countries with a larger power distance culture are less likely to voice their concerns to their colleagues as well as their managers, because they are socialized to avoid direct conflict with other people and to uncritically receive and obey orders from their bosses (Hofstede, 1991). This is supported by further evidence showing that compared to people in countries with a small power distance culture such as the USA, people in countries with a large power distance culture such as Japan tend to express their anger less openly (Argyle, Hengerson, Bond, Iizuka, and Contarello, 1986), display their frustration in ritualistic instead of direct ways during negotiations (Kirkbride, Tang, and Westwood, 1991), and hide their negative feelings about their bosses (Noesjirwan, 1978). In the current study, we are particularly interested in whether the level of employee opinion withholding across organizational units located in different countries is systematically related to cultural power distance. Based on the logic that people in large power distance countries are more accepting of the decisions of people in powerful positions, we expected that:

Hypothesis 1: Cultural power distance is positively related to the level of employee opinion withholding in different countries. 


\section{Stimulation of Participation}

According to Morrison and Milliken (2000), two major organizational factors form the 'raw materials' for a collective silence to develop: (1) organizational structures and policies, and (2) managerial practices and behavior. These structural features and managerial practices may affect how employees make sense of the work environment by providing socially constructed cues (Berger and Luckmann, 1967) about the extent to which the voices of employees are encouraged or discouraged. When organizations adopt a centralized decision-making structure and lack a formal mechanism or channel through which employees can express their opinions, concerns, and dissenting views about their organizations to management (Foegen, 1999), employees may form a collective interpretation that their opinions are not welcome, and thus most of the members in the organization would choose to remain silent (Morrison and Milliken, 2000). In addition, organizational silence may be caused by informal managerial behavior and practices. Managers may simply ignore the opinions and concerns of employees, reject or discount negative feedback from them (Ilgen, Fisher, and Taylor, 1979; Krefting and Powers, 1998), and even become annoyed when receiving unwanted messages (Rosen and Tesser, 1970). As a result, employees may form a collective conclusion that speaking up is of no use and may even be risky (Saunders et al., 1992).

Drawing on Morrison and Milliken's (2000) theoretical model, we identify two voice mechanisms that may reduce the level of organizational silence: the extent to which employees are formally involved in activities of decision-making and feedback (structural), and the degree to which a participative climate is nurtured by management (social). We use the term formalized employee involvement to refer to the extent of employee involvement in various formalized activities such as quality management meetings, management change meetings, team-building programs, and so forth. It has been well documented in the literature that formalized schemes for employee involvement are likely to increase work performance and the willingness of employees to take on more responsibilities (e.g., Gollan and Davis, 2001; Kim, 2002; Mackie, Holahan, and Gottlieb, 2001; Markey, 2001). Moreover, the findings of Coye and Belohlav's (1995) study suggest that programmatic efforts to involve employees tend to encourage individual employees to actively participate in decision-making processes and to give their suggestions to the organization. The presence of this structural-type voice mechanism not only provides an infrastructure that makes it easier for employees to voice their concerns about organizational matters, but also obliges employees to give suggestions. Therefore, organizational units with high degrees of formalized employee involvement are likely to have low levels of collective behavior of withholding opinions about organizational matters among the employees. 
A participative climate refers to the employees' collective perception of the extent to which new ideas, suggestions, and even dissenting views are encouraged by management. This collective perception may result from the existence of a structural voice mechanism in the organization as discussed above. However, a participative climate may also be created by the social interactions of employees with their managers and colleagues in the organization (Morrison and Milliken, 2000). For example, Kopelman, Brief, and Guzzo (1990) pointed out that, for a specific climate to develop, managers should establish an appropriate organizational structure and policies as well as provide employees with social support. Moreover, prior research suggests that the behavior of supervisors plays a vital role in providing subordinates with empowering experiences (Deci, Connell, and Ryan, 1989). In addition, the social information processing theory has long suggested that employee attitudes toward and perceptions of their organization are largely influenced by how their co-workers assess the organization (Salancik and Pfeffer, 1978; Weick, 1995).

The collective perception that employee participation is welcome in the unit may raise employees' aspirations for influence, and thus their willingness to voice their opinions and concerns (cf. Leana et al., 1992; Marchington et al., 1994; Tesluk, Farr, Mathieu and Vance, 1995). For instance, research has revealed that employees are more likely to speak up when they are given greater encouragement to argue (Gorden et al., 1988) and experience a more open way of managing employee voices from their supervisors (Saunders et al., 1992). Based on both quantitative and qualitative data, Edmondson (2003) found that members of interdisciplinary teams, which were formed to deal with challenging tasks, were more likely to voice their opinions and concerns regarding important work issues when the team leaders created a climate of 'speaking up' by actively encouraging the members to speak up, by articulating a motivating rationale for change and for speaking up, and by creating a sense of psychological safety about speaking out. Moreover, in their recent work, Piderit and Ashford (2003) suggested that in order to encourage female managers to openly discuss issues of gender equity, senior managers should build a supportive climate where women managers feel less at risk.

In short, a participative climate may be seen as a social-type voice mechanism, which may encourage employees to express their opinions, and thus, reduce the overall level of opinion withholding in an organization. Taken together, we expect that both the structural mechanism of formal employee involvement and the social mechanism of a perception of a participative climate should be useful in inducing employees to voice their opinions or in reducing the extent to which they withhold their opinions, resulting in the following hypothesis.

\section{Hypothesis 2: Formalized employee involvement and a perceived participative climate are negatively related to employee opinion withholding.}




\section{Voice Mechanisms and Power Distance}

Morrison and Milliken (2000) argued that since employees with a larger power distance orientation tend to uncritically accept the actions of those in authority, it may be more difficult for managers to encourage these people to speak up because such behavior is inconsistent with their ingrained cultural understanding. Findings from cross-cultural studies confirm that subordinates from countries with a large power distance culture tend to respond less positively to management practices aimed at encouraging more employee participation and involvement in decisionmaking. For instance, Eylon and Au's (1999) study suggests that employee participation does not necessarily lead to increased job satisfaction and job performance for people from countries with a large power distance culture. Rather, their findings indicate that people from countries with a larger power distance culture exhibited higher levels of job performance in less participative situations. Likewise, Robert et al. (2000) reported a negative relationship between empowering practices and job satisfaction in India, which has a large power distance culture. Further, Huang and Van de Vliert's (2003) 49-country study demonstrates that intrinsic job characteristics, such as job autonomy, produce more job satisfaction in countries with a smaller power distance culture. The above evidence suggests that participative management practices are less effective in countries with a larger power distance culture.

Furthermore, it has been suggested that human resource practices (HR practices) are more likely to enhance firm performances if the practices fit the external environment of the firm (Becker and Gerhart, 1996). Empirical studies have not only focused on the alignment of HR practices with the competitive strategies and business environment of a firm (Huselid, 1995), but have also paid increasing attention to the fit between HR practices and the broader socio-cultural environment (Brewster, 2004). For instance, Aycan, Kanungo, and Sinha (1999) have demonstrated that socio-cultural environmental forces such as power distance tend to give rise to less participative $H R$ practices, suggesting that more participative $H R$ practices cannot fit into the socio-cultural environment of a society with a large power distance culture. Based on the above discussion, the two mechanisms of formalized employee involvement and participative climate should have different effects on the levels of employee opinion withholding, depending on the level of power distance in the country in which the employees are located. We hypothesized that:

Hypothesis 3a: The negative relationship between formalized employee involvement and employee opinion withholding is weaker in countries with a large power distance culture than in countries with a small power distance culture.

Hypothesis 3b: The negative relationship between perceived participative climate and employee opinion withholding is weaker in countries with a large power distance culture than in countries with a small power distance culture. 


\section{Internal Fit of Voice Mechanisms}

Huselid (1995) has identified two types of fit with regard to human resource management practices, external fit and internal fit. External fit refers to the match between HR practices and the external environment of the firm. The fact, as discussed above, that either formalized involvement or a participative climate may not be effective at reducing the level of organizational silence in countries with a large power distance culture can be seen as an example of the mismatch between management practices and external cultural context. Internal fit refers to the match among HR practices. Bowen and Ostroff (2004) have highlighted that the match among various $\mathrm{HR}$ practices may send a clear message to employees about the goals and core values of an organization. Yet, a mismatch among various $H R$ practices may produce inconsistent and confusing messages, which may make employees less receptive towards the practices. A formalized involvement system may be used to encourage employees to voice their opinions. However, if the employees have a collective perception, based on informal interactions with managers and colleagues, that the company does not welcome the participation of employees, formalized involvement will be less likely to break the silence.

In fact, the literature has suggested that structural (e.g., formalized employee involvement) and social (e.g., participative climate) voice mechanisms may strengthen and reinforce each other's positive effect on employee voice. For instance, prior studies have suggested that formally involving employees in decision-making may not be enough to make them feel that the opinions of employees are welcome, unless they are actually encouraged by management to speak up (Coye and Belohlav, 1995). Likewise, Johnson, Donohue, Atkin, and Johnson (2001) found that when employees were involved in formal feedback systems, they tended to exhibit a high level of innovative behavior and were willing to contribute to decision-making by voicing their opinions. Employees were even more likely to give their opinions when managers created a climate of information sharing. Spencer (1986) held that an informal participative climate helps reinforce and sustain formal participative activities that are conducive to the voicing of opinions by employees. Edmondson's (2003) recent qualitative study also showed that the setting up of cross-disciplinary teams did not necessarily lead to better decisions and more voicing by employees. Only when managers actively intervened in organizational hierarchies to create a sense of safety and a climate to speak up, did the team members voice more opinions and concerns. Hence, a strong participative climate may reinforce the effect of formalized employee involvement on employee opinion withholding. However, this joint effect of structural and social voice mechanisms may vary from country to country.

In countries with a small power distance culture, participative management in any form is anticipated by employees. Yet, formalized employee involvement and a participative climate are more novel and unexpected in countries with a large 
power distance culture, representing a mismatch between management practices and cultural values. In such a culture, an internal fit among various participative management practices becomes critical to sending a strong and clear message to the employees that employees are encouraged to voice their opinions. Specifically, formalized employee involvement may be more likely to reduce organizational silence when this practice is carried out in organizational units with a stronger participative climate, especially in large power distance countries. In large power distance countries, organizations may need both structural and social voice mechanisms to reinforce the collective voice behavior, whereas in small power distance countries, such reinforcement is less critical and discernable. Consequently, we hypothesized that:

Hypothesis 4: Perceived participative climate has a stronger moderating effect on the negative relationship between formalized employee involvement and employee opinion withholding in large power distance countries than that in small power distance countries.

\section{METHOD}

\section{Sample}

The data were drawn from a survey conducted in 1997 in a multinational corporation. The purpose of the survey was to examine employees' attitudes towards their jobs and the organization. Questionnaires were administered by the management. All of the items were translated into the languages of the countries under investigation by professional translation agencies in those countries. The employees were told that the responses to questionnaires would be kept completely anonymous so that the management would not be able to identify the respondents. The response rate was $78 \%$ and the final analysis was based on a sample of 136,018 respondents in 421 organizational units in 24 countries with per capita incomes ranging from US $\$ 369$ per year to US $\$ 26,900$ per year. Expatriates from the country in which the company's headquarters was located were excluded from the sample. The sample was made up of $35 \%$ females and $65 \%$ males. The average age was 35.5 years, and the average period of tenure was 11.2 years. Appendix A shows the list of 24 countries along with some essential information included in this study. Included in these 24 countries are Singapore and Taiwan, which represent the Chinese culture.

\section{Dependent Variable}

Employee opinion withholding. We measured employee opinion withholding using 21 items covering five aspects of the organization. These 21 items are listed below in Table 1. For example, on the aspect of performance appraisals, the respondents were asked if their last performance appraisal helped: (a) to identify their strengths 
and weaknesses relative to their job; (b) to improve their job performance; (c) to identify their training needs. The respondents were asked to rate each item on a five-point scale, with 1 indicating very poor and 5 indicating very good. In addition to these choices, the respondents could also choose a sixth option, 'No Opinion.' Similarly, they were asked to respond to four other groups of questions. These questions were proposed by the management of the company at headquarters because these questions were related to several organizationwide human resource management practices during the period of data collection. An employee's tendency to withhold opinions about the organization was measured by calculating the proportion of the number of times 'No Opinion' was indicated to the total number of items (the number of 'No Opinions' was divided by 21 ).

Table 1. Items of Employee Opinion Withholding

I. How do you rate your last performance appraisal on the following: $(1=$ very good, $5=$ very poor; $6=$ no opinion)

1. Helping you identify your strengths and weaknesses relative to your job?

2. Helping you improve your job performance?

3. Helping you identify your training needs?

4. Helping you in your career development and planning?

5. Helping you and your boss identify and agree on clear performance criteria for next year?

II. In your judgment, how good a job is the management of your location doing in: $(1=$ very good, 5 very poor; $6=$ no opinion)

6. Providing leadership?

7. Following through on decisions taken?

8. Monitoring the results of actions taken?

III. Customer day

9. Overall, how do you rate customer day at your location? $(1=$ very good, $5=$ very poor; $6=$ no opinion)

IV. Please evaluate your company in relation to its competitors in your industry or line of business on the following: ( $1=$ the best, $4=$ not as good as most; $5=$ no opinion)

10. Quality of products.

11. Image of products.

12. Developing new technology.

13. Developing new products and services.

14. Meeting customer demands for products and services on time.

15. Responding rapidly to market changes.

V. Please indicate the amount of emphasis that you feel should be placed on the following as channels of communication: ( $1=$ more emphasis, $3=$ less emphasis; $4=$ no opinion)

16. Your immediate boss.

17. Managers at your location.

18. Departmental meetings.

19. Inter-departmental/inter-functional meetings.

20. Location-wide meetings.

21. Publications/newsletters for your location. 
To test the reliability of this construct, we calculated the number of 'No Opinions' on each of the five aspects and checked the intercorrelations of the five variables. We found that an employee who was silent about one aspect of the organization was also likely to be silent about another aspect of the organization ( $\alpha=0.67)$. To check the cross-national equivalence of the employee opinion withholding construct, we computed the within-country Cronbach's alphas of the five items in each country following the procedure suggested by Peterson et al. (1995). As illustrated in Appendix A, the alpha coefficients ranged from 0.45 to 0.76 . The alpha was lower than 0.60 in three out of the 24 countries (Columbia, Portugal, Turkey) indicating that the construct has modest cross-national equivalence. Past research has shown that relative to male, old, long-tenured employees, and employees at high levels of the organization, those who are female, young, short-tenured, and at low levels of the organization are more likely to remain silent about organizational issues (Boroff and Lewin, 1997; Milliken et al., 2003). To further validate the measurement of silence, we correlated employee opinion withholding with gender (measured using a dummy variable: $0=$ female, $1=$ male), age, organizational tenure, and job level (measured using a dummy variable: $0=$ blue-collar workers, clerks, administrators, sales representatives; 1 = professionals, engineers, supervisors, and middle managers). Consistent with previous findings, we found that employee opinion withholding was negatively related to gender $(r=-0.12, p<0.01)$; age $(r=-0.06$, $p<0.01)$; organizational tenure $(r=-0.08, p<0.01)$; and job level $(r=-0.16$, $p<0.01)$. These results provide some confidence in the validity of this dependent variable.

\section{Independent Variables}

Formalized employee involvement. The multinational company implemented a total quality management (TQM) program before and during the period in which the data were collected. Several TQM-related activities for employee involvement were formally introduced in subsidiaries across the 24 countries. Thus, formalized employee involvement was measured using seven items about the TQM-type of employee involvement $(1=$ To No Extent to $5=$ To a Very Great Extent; $\alpha=0.89)$ : 'To what extent have you been involved in the following: (a) quality management meetings; (b) management change meetings; (c) follow-up activities after quality management meetings and management change meetings; (d) achieving ISO-9000 certification; (e) product quality analysis activities; (f) team-building programs; (g) customer service improvement actions.'

Perceived participative climate. Perceived participative climate is a four-item, five-point scale ( $1=$ Disagree to $5=$ Agree; $\alpha=0.72)$ : 'Our location has established a climate where employees can challenge our traditional way of doing things'; 'Our location has established a climate where employees can communicate openly with those 
above them without fear of reprisal'; 'People in my department are encouraged to come up with innovative solutions to work-related problems'; 'My immediate boss is usually receptive to suggestions for change from employees.'

Power distance. Hofstede's (1991) power distance index (ranging from 1 to 100) was used as the operationalization of cultural power distance.

\section{Aggregation to Organizational Unit Level}

We examined whether the scores of the individual respondents on the employee opinion withholding, formalized employee involvement, and participative climate scales could be aggregated to the organizational unit level of analysis. First, a oneway analysis of variance was conducted with organizational unit code as the independent variable and employee opinion withholding, formalized employee involvement, and participative climate as the dependent variables. The results of this analysis revealed highly significant organizational effects (Employee opinion withholding: $F=21.705, p<0.001$; Formalized employee involvement: $F=49.544$, $p<0.001$; Perceived participative climate: $F=28.406 ; p<0.001)$. Then, we calculated the ICC(1) and ICC(2) for each scale (see James, 1982) and found scale values of 0.09 and 0.95 , respectively for employee opinion withholding, 0.15 and 0.98 for formalized employee involvement, and 0.07 and 0.96 for perceived participative climate. Finally, we computed the $R_{w g}$ for each scale in each organizational unit. We found a median value of $0.99(\mathrm{SD}=0.02$; range $0.80-1.00)$ for employee opinion withholding, a median value of 0.89 (SD $=0.45$, range 0.60-1.00) for formalized employee involvement, and a median value of 0.85 (SD $=0.46$, range $0.62-1.00$ ) for perceived participative climate. These results suggest a convergence of employee perceptions on the withholding of opinions and voice mechanisms in each organizational unit. Taken together, the reliability and validity results suggest that the aggregation of the three variables to the level of the organizational unit was justified.

\section{Control Variables}

Since, as shown in Appendix A, the Cronbach's alpha of employee opinion withholding varied from country to country, we entered the Cronbach's alpha obtained from each country into the model and controlled for the difference in the Cronbach's alphas of the employee opinion withholding construct across the 24 countries. The average age of the respondents, the average organizational tenure of the respondents, the percentage of male respondents, and the percentage of white-collar employees in each country could affect the overall level of employee opinion withholding of the respondents in the country. Hence, we controlled for the effects of these variables at the country level. Age and organizational tenure 
were measured in number of years. We used dummy variables to represent differences in gender $(0=$ female; $1=$ male $)$ and job category $(0=$ blue-collar employees; $1=$ white-collar employees), and calculated the percentages of female employees and white-collar employees in each country. Past research has shown that national wealth and cultural individualism are strongly correlated with cultural power distance (Hofstede, 1991). We therefore controlled for the effects of national wealth and cultural individualism. Wealth was measured using Gross National Product per capita (GNP) retrieved from a statistical reference book, National Cultures of the World (Parker, 1997). Cultural individualism was measured using Hofstede's (1991) index.

In addition, at the organizational unit level, the average age of the respondents, the average organizational tenure of the respondents, the percentage of male respondents, and the percentage of white-collar employees may also influence the collective behavior of employee opinion withholding in each unit. Therefore, we controlled for the effects of these variables at the unit level too.

\section{Analysis}

The model that we proposed integrates two levels of analysis, country-level analysis and organizational unit-level analysis. Statistically, the integration of the two levels of analysis can be achieved by using hierarchical linear modeling (HLM). Hierarchical linear modeling or multilevel modeling is a statistical technique designed to analyze data with a nested structure, such as organizational units nested within countries. In such a nested data structure, the organizational units are not randomly distributed across countries. As a result, bias may occur when the number and the characteristics of organizational units differ from country to country (Goldstein et al., 1998). Moreover, organizational units in a particular country, sharing the same national and cultural environment, are likely to be more homogeneous than organizational units in different countries. Simple one-level multiple regression techniques would lump all of the organizational units together and ignore the fact that, as a result of the potential statistical dependence among observations, the standard errors will be underestimated, leading to overestimation of the level of significance. HLM can provide greater assurance that the findings will not simply be the result of the distribution of organizational units across countries, the statistical dependence in the data, and varying sample sizes across countries, as these factors are less likely to affect HLM coefficients (Goldstein et al., 1998).

Data analyses were performed using Mlwin, which is a computer package for HLM (Goldstein et al., 1998). Mlwin produces an estimate for each predictor variable along with the associated standard error. These estimates are comparable to the unstandardized regression coefficients in an ordinary regression analysis, and their level of significance can be tested using t-distribution tests. Moreover, Mlwin 
produces a statistic called the deviance, which indicates how well a given model fits the data. If two models are nested, the difference in the deviances of the two models has a chi-square distribution with degrees of freedom equal to the difference in the number of parameters estimated. A chi-square test can then be performed to examine whether the more general model fits significantly better than the simpler model.

\section{RESULTS}

Table 2 provides an overview of summary statistics and correlations between all of the variables at the organizational unit-level. Table 3 shows the results of the HLM analysis with improvement of model fit statistics for each step. In Step 1, we entered all of the country-level and organizational unit-level control variables. To test Hypothesis 1, we entered cultural power distance in Step 2. As expected, we found a positive and moderate relationship between cultural power distance and employee opinion withholding $\left(b=0.15, p<0.05 ; \Delta \chi^{2}=3.23, d f=1, p<0.10\right.$; $\left.\Delta R^{2}=0.02\right)$. Thus, Hypothesis 1 was marginally supported. In Step 3, we put formalized employee involvement and participative climate into the model. The significant negative coefficients $(b=-0.26, p<0.001 ; b=-0.16, p<0.001$, formalized employee involvement and participative climate, respectively) and a significant improvement in the fit of the model $\left(\Delta \chi^{2}=97.7, d f=2, p<0.001 ; \Delta R^{2}=0.16\right)$ indicated that, at the organizational unit-level, these two voice stimulants were negatively related to employee opinion withholding. This supports Hypothesis 2. In Step 4, we tested whether the links between the two voice mechanisms and employee opinion withholding varied significantly across nations. A highly significant increase in model fit $\left(\chi^{2}=15.86, d f=3, p<0.001\right)$ indicated that there were considerable variations in the two slopes across countries. In other words, formalized employee involvement and participative climate did not reduce levels of silence to the same extent across nations. In Step 5, we tested the cross-level moderating effects of cultural power distance on the relationship between the voice mechanisms and the withholding of opinions. A significant interactive effect of formalized employee involvement and power distance $(b=0.09 ; p<0.05)$ indicated that the negative link between formalized employee involvement and employee opinion withholding was weaker in countries with a large power distance culture. Therefore, Hypothesis 3 a was supported. However, we did not find a significant interactive effect of participative climate and cultural power distance. Thus, Hypothesis $3 \mathrm{~b}$ was not supported.

In the final step, we found that formalized employee involvement, participative climate, and cultural power distance had a significant cross-level, three-way interactive effect on employee opinion withholding $\left(b=-0.09, p<0.05 ; \Delta \chi^{2}=11.61\right.$, $\left.d f=1, p<0.001 ; \Delta R^{2}=0.04\right)$. The plots of this interactive effect are shown in Figure 1. To determine whether the forms of the interactions matched those raised 
Table 2. Organizational unit-level means, standard deviations, and correlations

\begin{tabular}{|c|c|c|c|c|c|c|}
\hline & $M$ & $S D$ & 1 & 2 & 3 & 4 \\
\hline $\begin{array}{l}\text { 1. Alpha of employee } \\
\text { opinion withholding }\end{array}$ & 0.65 & 0.05 & - & & & \\
\hline 2. Country-level mean age & 37.40 & 5.50 & -0.08 & - & & \\
\hline 3. Country-level mean tenure & 7.40 & 2.87 & $0.20^{* *}$ & $0.75^{* *}$ & - & \\
\hline $\begin{array}{l}\text { 4. Country-level percentage } \\
\text { of males }\end{array}$ & 32.43 & 14.76 & $0.16^{* *}$ & $-0.23^{* *}$ & $-0.50^{* * *}$ & - \\
\hline $\begin{array}{l}\text { 5. Country-level percentage } \\
\text { of white-collar }\end{array}$ & 48.64 & 11.66 & $0.23^{* *}$ & $-0.63^{* *}$ & $-0.60^{* *}$ & $0.43^{* *}$ \\
\hline 6. National wealth & $16,004.06$ & $7,885.28$ & $-0.24 * *$ & $0.49 * *$ & $0.23^{* *}$ & $0.15^{* *}$ \\
\hline 7. Cultural individualism & 66.82 & 23.55 & $-0.38^{* *}$ & $0.61^{* *}$ & $0.28^{* *}$ & -0.07 \\
\hline $\begin{array}{l}\text { 8. Organizational unit-level } \\
\text { mean age }\end{array}$ & 34.36 & 6.80 & $-0.15^{* *}$ & $0.69 * *$ & $0.53^{* * *}$ & $-0.21^{* *}$ \\
\hline $\begin{array}{l}\text { 9. Organizational unit-level } \\
\text { mean tenure }\end{array}$ & 7.25 & 4.54 & 0.07 & $0.39^{* *}$ & $0.61^{* *}$ & $-0.37^{* *}$ \\
\hline $\begin{array}{l}\text { 10. Organizational unit-level } \\
\text { percentage of males }\end{array}$ & 29.95 & 19.07 & $0.12^{*}$ & $-0.20^{* *}$ & $-0.34^{* * *}$ & $0.54^{* *}$ \\
\hline $\begin{array}{l}\text { 11. Organizational unit-level } \\
\text { percentage of white-collar }\end{array}$ & 31.61 & 30.34 & $0.14^{* *}$ & $-0.23^{* *}$ & $-0.24^{* *}$ & $0.25^{* *}$ \\
\hline 12. Power distance & 49.52 & 18.43 & $0.40 * *$ & $-0.39 * *$ & $-0.13^{* *}$ & $0.19^{* *}$ \\
\hline $\begin{array}{l}\text { 13. Formalized employee } \\
\text { involvement }\end{array}$ & 2.13 & 0.53 & $0.34^{* *}$ & $-0.23^{* * *}$ & -0.01 & $0.11^{*}$ \\
\hline 14. Participative climate & 3.55 & 0.38 & $-0.12^{*}$ & $0.13^{* *}$ & -0.02 & $-0.19 * *$ \\
\hline $\begin{array}{l}\text { 15. Employee opinion } \\
\text { withholding }\end{array}$ & 0.14 & 0.06 & 0.05 & $-0.11 *$ & $-0.13^{* *}$ & $0.15^{* *}$ \\
\hline
\end{tabular}

Notes: $\mathcal{N}=421 .{ }^{*} p<0.05 ;{ }^{* *} p<0.01 ;{ }^{* * *} p<0.001$, two-tailed.

in Hypothesis 4, we tested the simple slopes of the link between employee involvement and opinion withholding in four conditions: (1) small power distance (one standard deviation higher) and a weak participative climate (one standard deviation higher), (2) small power distance (one standard deviation higher) and a strong participative climate (one standard deviation lower), (3) large power distance (one standard deviation lower) and a weak participative climate (one standard deviation higher), and (4) large power distance (one standard deviation lower) and a strong participative climate (one standard deviation lower). In support of Hypothesis 4 , formalized employee involvement was negatively linked to employee opinion withholding in countries with a small power distance culture, irrespective of the level of the participative climate in the organizational units (a simple slope for a weak participative climate: $b=-0.32, p<0.001$; a simple slope for a strong participative climate: $b=-0.50, p<0.001)$. In countries with a large power distance culture, however, employee involvement was not related to employee opinion withholding when levels of participative climate were low (simple slope test: $b=-0.10$, n.s.). In these countries, formalized employee involvement was negatively and sig- 
Table 2. (cont.)

\begin{tabular}{llllllllllll}
\hline 5 & 6 & 7 & 8 & 9 & 10 & 11 & 12 & 13 & 14 & 15 \\
\hline
\end{tabular}

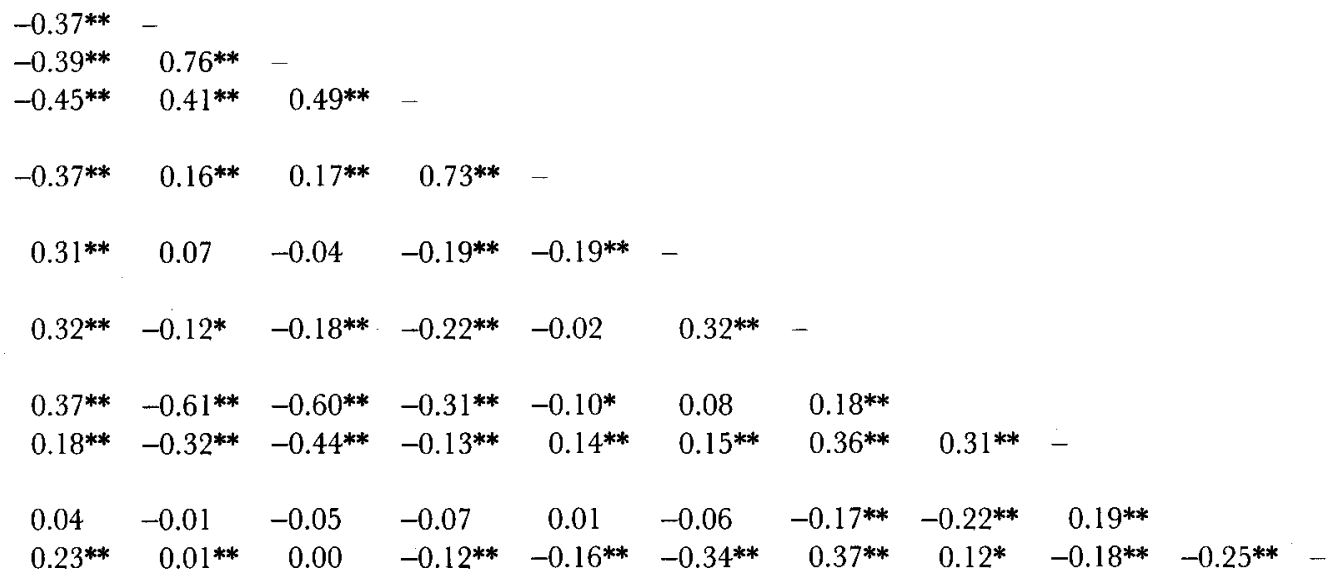

nificantly related to employee opinion withholding only when the organizational units had high levels of participative climate (simple slope test: $b=-0.29$, $p<0.001$ ).

\section{DISGUSSION}

Systematic and collective silence in organizations may have negative effects on organizational change and development in an increasingly competitive market (Morrison and Milliken, 2000). Thus, it is vitally important for managers to encourage more employees to voice their concerns, opinions, and dissenting views about their organizations. The globalized business environment presents new challenges to multinational companies which desire to reduce organizational silence and promote innovative behavior in culturally diverse nations. The current crossnational study yielded results that provide insight into how the national cultural value of power distance influences organizational silence and what voice mechanisms may reduce silence in different cultures. 
Table 3. Multilevel analyses of country and organizational unit-level correlates of employee opinion withholding

\begin{tabular}{|c|c|c|}
\hline Variables & Standardized Beta & Standard Error \\
\hline \multicolumn{3}{|l|}{ Step 1 Control variables } \\
\hline \multicolumn{3}{|l|}{ Country-level variables } \\
\hline Alpha coefficients of employee opinion withholding & 1.58 & 1.46 \\
\hline Mean age & -0.21 & 0.29 \\
\hline Mean tenure & 0.30 & 0.21 \\
\hline Percentage of male respondents & -0.01 & 0.01 \\
\hline Percentage of white-collar employee respondents & 0.01 & 0.01 \\
\hline National wealth & 0.00 & 0.00 \\
\hline Cultural individualism & -0.04 & 0.10 \\
\hline \multicolumn{3}{|l|}{ Organizational unit-level variables } \\
\hline Mean age & $0.54 * * *$ & 0.14 \\
\hline Mean tenure & $-0.48 * * *$ & 0.08 \\
\hline Percentage of male respondents & $0.02 * * *$ & 0.00 \\
\hline Percentage of white-collar employee respondents & $0.01^{* * *}$ & 0.00 \\
\hline $\begin{array}{l}\text { Increase in model fit } \\
\Delta R^{2} \text { for step } 1\end{array}$ & \multicolumn{2}{|c|}{$\begin{array}{c}\chi^{2}(11)=209.96^{* * *} \\
{[0.38]}\end{array}$} \\
\hline \multicolumn{3}{|l|}{ Step 2} \\
\hline Power distance (PD) & $0.15^{*}$ & 0.07 \\
\hline $\begin{array}{l}\text { Increase in model fit } \\
\Delta R^{2} \text { for step } 2\end{array}$ & \multicolumn{2}{|c|}{$\begin{array}{c}\chi^{2}(1)=3.23^{+} \\
{[0.02]}\end{array}$} \\
\hline \multicolumn{3}{|l|}{ Step 3} \\
\hline Formalized employee involvement (FEI) & $-0.26^{* * *}$ & 0.04 \\
\hline Participative climate $(\mathrm{PC})$ & $-0.16^{* * *}$ & 0.04 \\
\hline $\begin{array}{l}\text { Increase in model fit } \\
\Delta R^{2} \text { for step } 3\end{array}$ & \multicolumn{2}{|c|}{$[0.16]$} \\
\hline \multicolumn{3}{|l|}{ Step 4 (testing the slopes) } \\
\hline FEI & $-0.25^{* * *}$ & 0.07 \\
\hline $\mathrm{PC}$ & $-0.15^{* * * *}$ & 0.07 \\
\hline $\begin{array}{l}\text { Increase in model fit } \\
\Delta R^{2} \text { for step } 4^{\mathrm{a}}\end{array}$ & \multicolumn{2}{|c|}{$\chi^{2}(3)=15.86^{* * *}$} \\
\hline \multicolumn{3}{|l|}{ Step 5} \\
\hline $\mathrm{FEI} \times \mathrm{PD}$ & $0.09 *$ & 0.04 \\
\hline $\mathrm{PC} \times \mathrm{PD}$ & 0.04 & 0.06 \\
\hline $\mathrm{PC} \times \mathrm{FEI}$ & -0.04 & 0.03 \\
\hline $\begin{array}{l}\text { Increase in model fit } \\
\Delta R^{2} \text { for step } 5\end{array}$ & \multicolumn{2}{|c|}{$\begin{array}{c}\chi^{2}(3)=6.79^{+} \\
{[0.04]}\end{array}$} \\
\hline \multicolumn{3}{|l|}{ Step 6} \\
\hline $\mathrm{PC} \times \mathrm{FEI} \times \mathrm{PD}$ & $-0.09^{*}$ & 0.04 \\
\hline $\begin{array}{l}\text { Increase in model fit } \\
\Delta R^{2} \text { for step } 6\end{array}$ & \multirow{2}{*}{\multicolumn{2}{|c|}{$\begin{array}{c}\chi^{2}(1)=11.61 \\
{[0.04]} \\
{[0.64]}\end{array}$}} \\
\hline Overall model adjusted $\mathrm{R}^{2}$ & & \\
\hline
\end{tabular}

Notes: ${ }^{+} p<0.10 .{ }^{*} p<0.05 .{ }^{* *} p<0.01 .{ }^{* * *} p<0.001$, two-tailed.

${ }^{\mathrm{a}}$ In this step, no $\Delta R^{2}$ was reported because no additional independent variables were added into the model. The model fit indicates whether there is significant variation in intercepts and slopes across nations. 

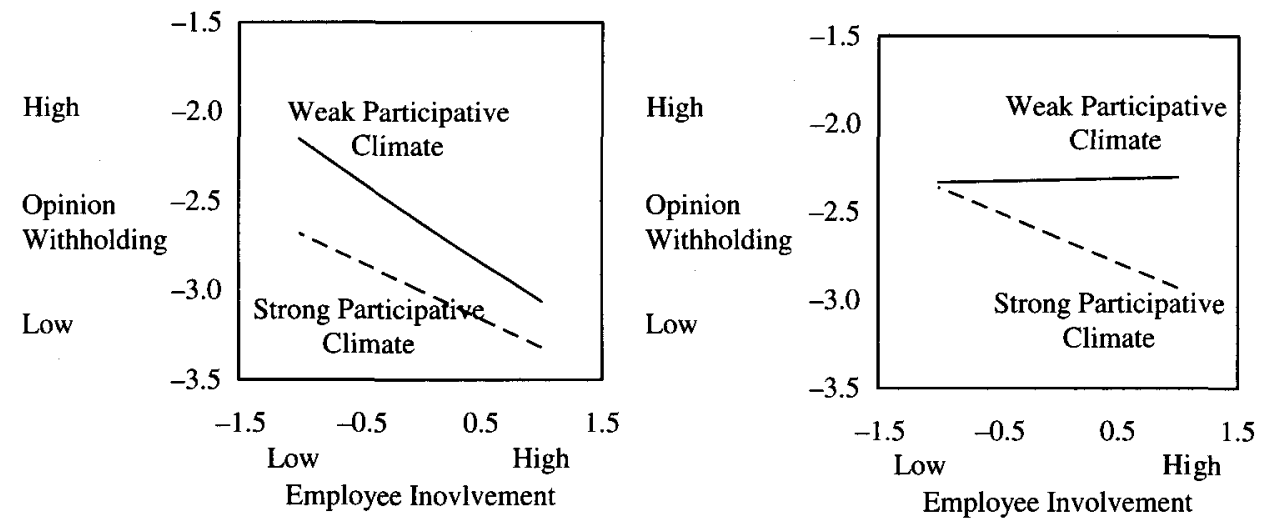

Figure 1. The joint effect of formalized employec involvement and participative climate on employee opinion withholding in high versus low power distance countries

In line with major findings in cross-national research that people in large power distance countries are more likely to comply with the orders of those in authority (Hofstede, 1991) and less likely to voice their concerns to their bosses (e.g., Argyle et al., 1986; Kirkbride et al., 1991; Noesjirwan, 1978; Smith, Dugan, Peterson, and Leung, 1998), we found that cultural power distance was positively related to the overall level of employee opinion withholding in organizational units, suggesting that management may need to make an extra effort and pay more attention to reducing organizational silence in large power distance cultures.

We then identified two voice mechanisms that can be used to reduce organizational silence, a structural mechanism of formalized employee involvement and a social mechanism of informally perceived participative climate. As predicted, the formalized employee involvement was associated more with lower levels of employee opinion withholding in countries with a small power distance culture than in countries with a large power distance culture. However, the relationship between perceived participative climate and employee opinion withholding did not differ significantly between small power distance countries and large power distance countries. Most interestingly, we found that an internal fit between the two voice mechanisms was important for countries with a large power distance culture. This finding suggests that in large power distance cultures, a formal mechanism alone is not sufficient to break the silence. There must also be a strong participative climate. Theoretically, this result accords well with the notion that employees with larger power-distance orientations tend to uncritically accept the actions of authority (Hofstede, 1991) and to respond less positively to managerial practices and organizational policies aiming at raising employee voices in organizations (cf. Eylon and Au, 1999; Robert et al., 2000). Therefore, in countries with a large 
power distance culture, more effort is needed to break the silence. Our findings also suggest that if the management practices do not fit into the socio-cultural environment of a nation, managers should ensure that there is an internal fit among various management practices in order to overcome problems resulting from the external misfit. In countries with a large power distance culture, involvement in any form (e.g., TQM-type involvement) is novel and unexpected. In fact, it may represent a mismatch between cultural values and management practices. As such, other mechanisms that help foster participation are needed to overcome this problem, such that a TQM-type involvement activity will only work (to a limited degree) in countries with a large power distance culture if participation is also encouraged in order to overcome the mismatch between management practices and cultural values.

\section{Future Research Directions}

Morrison and Milliken (2000) proposed that the climate of silence is caused by organizational structures and policies (the centralization of decision-making and lack of formal upward feedback mechanisms) and managerial practices (managers' negative attitudes towards the voicing of opinions by employees and the failure to informally solicit negative feedback). Building on this framework, we proposed and examined the effect of two important voice mechanisms, namely formalized employee involvement and participative climate, on organizational silence. Other structural and social voice mechanisms, such as the degree of decentralization of the organizational structure (Mintzberg, 1979) and leadership behavior (Burns, 1978), should be explored in future studies. It is conceivable that, in organizations with flatter and team-based structures, employees may find it easier to voice their concerns to higher-level authorities. Thus, these organizations may have lower levels of silence. Burns (1978) distinguished transformational leadership from transactional leadership. While transformational leaders tend to foster independent followers by inspiring them with visions and values and providing them with individualized support, transactional leaders merely focus on short-term goals and the proper exchange of resources. Hence, it is plausible to expect that transformational leadership will be more likely than transactional leadership to impede the development of a climate of organizational silence.

Since our results suggest that it is more difficult to reduce silence in countries with a large power distance culture, it becomes interesting to explore what voice mechanisms are more effective in reducing silence in these countries. For example, one way to encourage employees to voice their opinions is to establish selfmanaged teams, in which the authority to make decisions that can lead to the accomplishment of the team's work is given to the team members. In a quasiexperimental study conducted in the US, Erez, Lepine, and Elms (2002) found that the design of self-managed teams determines, among other things, the levels 
of employee voice. Specifically, they reported that compared to teams that relied on external evaluations and on the emergence of a leader, teams that carried out peer evaluations and rotated the position of leader among members had higher levels of voice. Given that, in large power distance cultures, people are used to passively receiving orders from superiors, future research can investigate whether teams that relied on external evaluations and on the emergence of leaders would be more rather than less effective in reducing organizational silence in these cultures.

Morrison and Milliken (2000) suggested that when organizational forces make employees fear that speaking up will cause negative repercussions and make them think that speaking up will have no use, they tend to remain silent about organizational issues (e.g., Ryan and Oestreich, 1991; Saunders et al., 1992). Although the mediating role of the psychological states of the employees in the link between organizational forces and the silence behavior of employees has been suggested for some time, they have not been empirically tested. Future research could test specifically whether voice mechanisms would reduce some negative effects and feelings, such as the anxiety, distrust in management, organizational cynicism, and the feeling of helplessness on the part of employees, which are presumably positively associated with organizational silence.

\section{Implications for China}

Employee involvement has been considered an indispensable element of total quality management practices (e.g., Daily and Bishop, 2003; Deming, 1986; Hua, Chin, Sun, and $\mathrm{Xu}, 2000$; Juran, 1988), which have been widely used in some major developing countries, including China. For example, a recent survey conducted in 71 Chinese firms revealed that among the ten indicators of total quality performance, namely leadership, processes, policy and strategy, impact on society, customer satisfaction, people management, supplier quality, employee involvement, quality assurance, and business results, employee involvement was the dimension that received the lowest rating (Hua et al., 2000). Similarly, based on data collected from 112 small Chinese firms with total quality management (TQM) practices, Lee (2004) found that only $47 \%$ of the firms adopted employee involvement programs. The unsuccessful implementation of and reluctance to adopt TQM-related employee involvement may have to do with the misfit between employee involvement practices and the large power distance culture in China. Our results clearly suggest that in order to use employee involvement activities to encourage more voice behavior in countries with a large power distance culture such as China, managers should establish a climate of participation in the first place to reinforce the message of employee participation. Noronha (2002) consistently noted in his qualitative study that to ensure the successful implementation of total quality management practices in the Chinese cultural context, managers 
should be open-minded towards the opinions of employees and create a climate of collective decision-making. Research to substantiate some of the claimed benefits of total quality management, including the reduction of organizational silence within the Chinese context, would be desirable.

\section{Limitations}

There are three major limitations to our study. First, we measured employee opinion withholding by calculating the number of 'No Opinions' the respondents indicated on 21 items concerning five aspects of the organization. This score on this measure shows that the employees had opinions about $86 \%$ of the time (or, on average, on 18 of the 21 items). This results in a small variance, not a good quality for a statistical analysis. Would the employees report more withholding of their opinion if the survey was not anonymous? However, non-anonymity may also reduce the overall response rate. On sensitive topics like the current issue, anonymity is an essential condition for participation. In fact, this method of measuring employee opinion withholding may be a conservative way of estimating the level of silence in the organization. A related limitation is that the respondents may have chosen 'No Opinion' because they truly had no ideas or no opinions about the specific organizational issues. However, the intercorrelations of employee opinion withholding among five different aspects of the organization $(\alpha$ $=0.67$ ) suggest that there is a systematic pattern of withholding opinions. Third, the relationships found in this study are correlational and provide no evidence of the direction of the relationships. All of the inferred causal relationships are based on theory and need further verification in future research using a longitudinal research method or experimentation.

\section{GONGLUSION}

In summary, the present study contributes to the extant literature on organizational voice by supporting Morrison and Milliken's (2000) idea that structural and social voice mechanisms are associated with organizational silence. In addition, we extend the model of organizational silence by showing that the effect of voice mechanisms on organizational silence varies across nations. Compared with countries with a small power distance culture, in countries with a large power distance culture, a better fit among various voice mechanisms is needed in order to more effectively reduce organizational silence.

\section{NOTE}

We would like to thank Anne Tsui and the three reviewers for their constructive comments on the drafts of this paper. 
Appendix A. Power Distance Scores, Individualism Scores, National Wealth, Percentage of White-collar Respondents, Number of Units, and Number of Respondents, and the Means, Standard Deviations, and Alpha Coefficients of Employee Opinion Withholding for each Nation

\begin{tabular}{|c|c|c|c|c|c|c|c|c|c|}
\hline \multirow[t]{2}{*}{ Nations } & \multirow[t]{2}{*}{$\begin{array}{l}\text { Power } \\
\text { distance }\end{array}$} & \multirow[t]{2}{*}{ Individualism } & \multirow{2}{*}{$\begin{array}{l}\text { National } \\
\text { wealth } \\
(U S D)\end{array}$} & \multirow{2}{*}{$\begin{array}{l}\text { Percentage of } \\
\text { white-collar } \\
\text { respondents }\end{array}$} & \multirow[t]{2}{*}{$\begin{array}{l}\text { No. of } \\
\text { establishments }\end{array}$} & \multirow[t]{2}{*}{$\begin{array}{l}\text { No. of } \\
\text { respondents }\end{array}$} & \multicolumn{3}{|c|}{$\begin{array}{l}\text { Employee opinion } \\
\text { withholding }\end{array}$} \\
\hline & & & & & & & $M$ & $S D$ & Alpha \\
\hline Austria & 11.00 & 90 & 20,200 & 47.7 & 22 & 4,586 & 0.10 & 0.17 & 0.69 \\
\hline Belgium & 65.00 & 75 & 23,950 & 58.5 & 14 & 6,121 & 0.21 & 0.23 & 0.72 \\
\hline Brazil & 69.00 & 38 & 2,680 & 66.2 & 20 & 10,328 & 0.17 & 0.18 & 0.63 \\
\hline Canada & 39.00 & 80 & 20,800 & 44.4 & 4 & 653 & 0.13 & 0.18 & 0.61 \\
\hline Colombia & 72.50 & 13 & 1,500 & 44.8 & 3 & 238 & 0.11 & 0.16 & 0.56 \\
\hline France & 68.00 & 71 & 20,400 & 42.8 & 38 & 8,987 & 0.14 & 0.19 & 0.69 \\
\hline Germany & 35.00 & 67 & 22,300 & 33.0 & 11 & 11,440 & 0.12 & 0.17 & 0.68 \\
\hline Holland & 38.00 & 80 & 18,300 & 45.4 & 94 & 24,532 & 0.15 & 0.19 & 0.62 \\
\hline India & 77.00 & 48 & 369 & 46.6 & 22 & 4,787 & 0.14 & 0.20 & 0.74 \\
\hline Indonesia & 78.00 & 14 & 680 & 69.1 & 8 & 1,750 & 0.12 & 0.15 & 0.62 \\
\hline Italy & 50.00 & 76 & 18,600 & 31.5 & 8 & 1,810 & 0.11 & 0.17 & 0.68 \\
\hline Japan & 54.00 & 46 & 26,900 & 17.4 & 6 & 1,787 & 0.14 & 0.20 & 0.65 \\
\hline Malaysia & 104.00 & 26 & 2,960 & 77.4 & 6 & 3,357 & 0.17 & 0.20 & 0.75 \\
\hline Mexico & 81.00 & 30 & 3,660 & 87.9 & 7 & 8,274 & 0.20 & 0.22 & 0.69 \\
\hline Pakistan & 55.00 & 14 & 410 & 43.2 & 6 & 846 & 0.11 & 0.14 & 0.60 \\
\hline Portugal & 63.00 & 27 & 9,000 & 55.1 & 4 & 1,113 & 0.07 & 0.13 & 0.58 \\
\hline S. Africa & 49.00 & 65 & 2,960 & 19.0 & 6 & 741 & 0.14 & 0.17 & 0.67 \\
\hline Singapore & 74.00 & 20 & 16,500 & 65.6 & 6 & 5,774 & 0.18 & 0.20 & 0.71 \\
\hline Spain & 57.00 & 51 & 13,200 & 42.1 & 13 & 1,481 & 0.11 & 0.18 & 0.73 \\
\hline Taiwan & 58.00 & 17 & 10,000 & 67.5 & 7 & 8,901 & 0.17 & 0.22 & 0.76 \\
\hline Thailand & 64.00 & 20 & 1,940 & 67.9 & 6 & 4,636 & 0.10 & 0.15 & 0.68 \\
\hline Turkey & 66.00 & 37 & 3,670 & 7.6 & 3 & 279 & 0.07 & 0.10 & 0.45 \\
\hline UK & 35.00 & 89 & 16,700 & 52.0 & 32 & 7,098 & 0.12 & 0.18 & 0.65 \\
\hline USA & 40.00 & 91 & 23,400 & 47.9 & 75 & 16,499 & 0.15 & 0.19 & 0.60 \\
\hline Total: & - & & & & 421 & 136,018 & & & \\
\hline
\end{tabular}

\section{REFERENCES}

Argyle, M., Hengerson, M., Bond, M., Iizuka, Y. and Contarello, A. (1986). 'Cross-cultural variations in relationship rules'. International Fournal of Psychology, 21, 287-315.

Ashford, S. J., Rothbard, N. P., Piderit, S. K. and Dutton, J. E. (1998). 'Out on a limb: The role of context and impression management in selling gender-equity issues'. Administrative Science Quarterly, 43, 23-57.

Aycan, Z., Kanungo, R. N. and Sinha, J. B. P. (1999). Organizational culture and human resource management practices: The model of culture fit. Fournal of Cross-Cultural Psychology, 30, 501-26.

Becker, B. and Gerhart, B. (1996). 'The impact of human resource management on organizational performance: Progress and prospects'. Academy of Management fournal, 39, 770-801.

Berger, P. L. and Luckmann, T. (1967). The Social Construction of Reality. New York: Doubleday.

Bies, R. J. and Tripp, T. M. (1999). 'Two faces of the powerless: Coping with tyranny'. In Kramer, R. M. and Neale, M. A. (Eds.), Power and Influence in Organizations (pp. 203-19). Thousand Oaks, CA: Sage.

Boroff, K. E. and Lewin, D. (1997). 'Loyalty, voice, and intent to exit a union firm: A conceptual and empirical analysis'. Industrial and Labor Relations Review, 51, 50-65. 
Bowen, D. and Ostroff, C. (2004). 'Understanding HRM-firm performance linkages: The role of the "strength of the HRM system"'. Academy of Management Reviere, 29, 203-21.

Bowen, F. and Blackmon, K. (2003). 'Spirals of silence: The dynamic effects of diversity on organizational voice'. Fournal of Management Studies, 40, 1393-417.

Brewster, C. (2004). 'Human resource practices in multinational companies'. In Gannon, M. J. and Newman, K. L. (Eds.), Handbook of Cross-Cultural Management (pp.126-41). Oxford: Blackwell.

Burns, J. M. (1978). Leadership. New York: Harper and Row.

Coye, R. W. and Belohlav, J. A. (1995). 'An exploratory analysis of employee participation'. Group and Organization Management, 20, 4-17.

Creed, W. E. D. (2003). 'Voice lessons: Tempered radicalism and the use of voice and silence'. Fournal of Management Studies, 40, 1503-36.

Daily, B. F. and Bishop, J. W. (2003). 'TQM workforce factors and employee involvement: The pivotal role of teamwork'. Journal of Managerial Issues, 15, 393-412.

Deci, E. L., Connell, J. P. and Ryan, R. M. (1989). 'Self-determination in a work organization'. Fournal of Applied Psychology, 74, 580-90.

Deming, W. E. (1986). The New Economics for Industry, Government, Education. Boston, MA: MIT Press.

Edmondson, A. C. (2003). 'Speaking up in the operating room: How team leaders promote learning in interdisciplinary action teams'. Fournal of Management Studies, 40, 1419-52.

Erez, M. (1994). 'Toward a model of cross-cultural industrial and organizational psychology'. In Dunnette, M. D. and Hough, L. M. (Eds.), Handbook of Industrial and Organizational Psychology (pp. 559-607). Palo Alto, CA, USA: Consulting Psychologists Press.

Erez, A., Lepine, J. A. and Elms, H. (2002). 'Effects of rotated leadership and peer evaluation on the functioning and effectiveness of self-managed teams: A quasi-experiment'. Personnel Psychology, 55, 932-47.

Eylon, D. and Au, K. Y. (1999). 'Exploring empowerment cross-cultural differences along the power distance dimension'. International Fournal of Intercultural Relations, 23, 373-85.

Foegen, J. H. (1999). 'Why not empowerment?' Business and Economic Review, 45, 31-3.

Goldstein, H., Rasbash, J., Plewis, I., Draper, D., Browne, W., Yang, M., Woodhouse, G. and Healy, M. (1998). A User's Guide to MLwiN. University of London.

Gollan, P. J. and Davis, E. M. (2001). 'Employee involvement and organizational change: The diffusion of high involvement management in Australian workplaces'. In Markey, R., Gollan, P., Hodgkinson, A., Chouraqui, A. and Veersma, U. (Eds.), Models of Employee Participation in a Changing Global Environment: Diversity and Interaction (pp. 56-80). Singapore: Ashgate.

Gorden, W. I., Infante, D. A. and Graham, E. E. (1988). 'Corporate conditions conducive to employee voice: A subordinate perspective'. Employee Responsibilities and Rights Fournal, 1, 101-11.

Hofstede, G. H. (1991). Cultures and Organizations: Software of the Mind. McGraw-Hill: London.

Hua, H., Chin, K. S., Sun, H. and Xu, Y. (2000). 'An empirical study on quality management practices in Shanghai manufacturing industries'. Total Quality Management, 11, 1111-22.

Huang, X. and Van de Vliert, E. (2003). 'Where intrinsic motivation fails to work: National moderators of intrinsic motivation'. Fournal of Organizational Behavior, 24, 159-79.

Huselid, M. (1995). 'The impact of human resource management practices on turnover, productivity, and corporate financial performance'. Academy of Management Journal, 38, 635-72.

Ilgen, D. R., Fisher, C. D. and Taylor, M. S. (1979). 'Consequences of individual feedback on behavior in organizations'. Journal of Applied Psychology, 64, 349-71.

James, L. R. (1982). 'Aggregation bias in estimates of perceptual agreement'. Journal of Applied Psychology, 67, 219-29.

Johnson, J. D., Donohue, W. A., Atkin, C. K. and Johnson, S. (2001). 'Communication, involvement, and perceived innovativeness'. Group and Organization Management, 26, 24-52.

Juran, J. M. (1988). Furan on Planning for Quality. New York, NY: Free Press.

Kim, S. (2002). 'Parcipative management and job satisfaction. Lessons for management leadership'. Public Administration Review, 62, 231-41.

Kirkbride, P. S., Tang, S. F. Y. and Westwood, R. I. (1991). 'Chinese conflict preferences and negotiating behaviour: Cultural and psychological influences'. Organization Studies, 13, 365-86.

Kopelman, R. E., Brief, A. P. and Guzzo, R. A. (1990). 'The role of climate and culture in productivity'. In Schneider, B. (Ed.), Organizational Climate and Culture (pp. 282-318). Oxford: Jossey-Bass.

Krefting, L. and Powers, K. J. (1998). 'Exercised voice as management failure: Implications of willing compliance theories of management and individualism for de facto employee voice'. Employee Responsibilities and Rights Journal, 11, 263-77. 
Leana, C. R., Ahlbrandt, R. S. and Murrell, A. J. (1992). 'The effects of employee involvement programs on unionized workers' attitudes, perceptions, and preferences in decision making'. Academy of Management Fournal, 35, 861-73.

Lee, C.Y. (2004). 'Perception and development of total quality management in small manufacturers: An exploratory study in China'. Fournal of Small Business Management, 42, 102-15.

Mackie, K. S., Holahan, C. K. and Gottlieb, N. H. (2001). 'Employee involvement management practices, work stress, and depression in employees of a human services residential care facility'. Human Relations, 54, 1065-92.

Marchington, M., Wilkinson, A., Ackers, P. and Goodman, J. (1994). 'Understanding the meaning of participation: Views from the workplace'. Human Relations, 47, 867-94.

Markey, R. (2001). 'Introduction: Global patterns of participation'. In Markey, R., Gollan, P., Hodgkinson, A., Chouraqui, A. and Veersma, U. (Eds.), Models of Employee Participation in a Changing Global Environment: Diversity and Interaction (pp. 3-22). Singapore: Ashgate.

Miceli, M. P. and Near, J. P. (1992). Blowing the Whistle. New York: Lexington Books.

Milliken, F. J., Morrison, E. W. and Hewlin, P. F. (2003). 'An exploratory study of employee silence: Issues that employees don't communicate upward and why'. Journal of Management Studies, 40, $1453-76$.

Mintzberg, H. (1979). The Structuring of Organizations: A Synthesis of the Research. London: Prentice Hall International.

Morrison, E. W. and Milliken, F. J. (2000). 'Organizational silence: A barrier to change and development in a pluralistic world'. Academy of Management Review, 25, 706-25.

Noesjirwan, J. (1978). 'A rule-based analysis of cultural differences in social behavior: Indonesia and Australia'. International Journal of Psychology, 13, 305-16.

Noronha, C. (2002). 'Culture-specific TQM in China: Case studies for theoretical consideration'. Asian Business and Management, 1, 125-45.

Parker, M. P. (1997). National Cultures of the World: A Statistical Reference. Westport, CT; London: Greenwood Press.

Piderit, S. K. and Ashford, S. J. (2003). 'Breaking silence: Tactical choices women managers make in speaking up about gender-equity issues'. Journal of Management Studies, 40, $1477-502$.

Premeaux, S. F. and Bedeian, A. G. (2003). 'Breaking the silence: The moderating effects of selfmonitoring in predicting speaking up in the workplace'. Fournal of Management Siudies, $\mathbf{4 0}$, $1537-62$.

Robert, C., Probst, T. M., Martocchio, J. J., Drasgow, F. and Lawler, J. J. (2000). 'Empowerment and continuous improvement in the United States, Mexico, Poland, and India: Predicting fit on the basis of the dimensions of power distance and individualism'. Journal of Applied Psychology, 85, $643-58$.

Rosen, S. and Tesser, A. (1970). 'On reluctance to communicate undesirable information: The MUM effect'. Sociometry, 33, 253-63.

Rusbult, G. E., Farrell, D., Rogers, G. and Mainous, A. G., III. (1988). 'Impact of exchange variables on exit, voice, loyalty, and neglect: An integrative model of response to declining job satisfaction'. Academy of Management Journal, 31, 599-627.

Ryan, K. D. and Oestreich, D. K. (1991). Driving Fear out of the Workplace: How to Overcome the Invisible Barriers to Quality, Productivity, and Innovation. San Francisco: Jossey-Bass.

Salancik, G. and Pfeffer, J. (1978). A social information processing approach to job attitudes and task design'. Administrative Science Quarterly, 23, 224-53.

Saunders, D. M., Sheppard, B. H., Knight, V. and Roth, J. (1992). 'Employee voice to supervisors'. Employee Responsibilities and Rights Journal, 5, 241-59.

Smith, P. B., Dugan, S., Peterson, M. F. and Leung, K. (1998). 'Individualism: Collectivism and the handling of disagreement. A 23 country study'. International fournal of Intercultural Relations, 22, $351-67$.

Spencer, D. G. (1986). 'Employee voice and employee retention'. Academy of Management Fournal, 29, 488-502.

Tesluk, P. E., Farr, J. L., Mathieu, J. E. and Vance, R. J. (1995). 'Generalization of employee involvement training to the job setting: Individual and situational effects'. Personnel Psychology, 48, $607-32$.

Van Dyne, L., Ang, S. and Botero, I. C. (2003). 'Conceptualizing employee silence and employee voice as multidimensional constructs'. Journal of Management Studies, 40, 1359-92. 
Weick, K. E. (1995). Sensemaking in Organizations. London: Sage.

Zand, D. E. (1972). 'Trust and administrative problem solving'. Administrative Science Quarterly, 17, 229-39.

Xu Huang (mshuangx@polyu.edu.hk) is an Associate Professor at the Department of Management and Marketing at the Hong Kong Polytechnic University. He received his Ph.D. from the University of Groningen, the Netherlands. His research interests include cross-cultural organizational psychology, employee empowerment, Chinese leadership behavior, organizational justice, and management issues in China.

Evert Van de Vliert (E.Van.de.Vliert@rug.nl) is a Professor of Organizational and Applied Social Psychology at the University of Groningen, the Netherlands. He received his Ph.D. from the Free University in Amsterdam in 1973, and is the recipient of the IACM Lifetime Achievement Award 2005. Van de Vliert's current research interests focus on cross-national organization psychology, with an emphasis on the impact of atmospheric thermoclimate on leadership and human resource management.

Gerben S. Van der Vegt (G.van.der.Vegt@rug.nl) is an Associate Professor of Organizational Behavior at the Department of Management and Organization at the University of Groningen, the Netherlands. He received his Ph.D. from the same University. His current research focuses on the processes associated with the integration of knowledge and expertise in work teams and organizations, effective team design, organizational diversity, and socialization.

Manuscript received: July 6, 2004

Final version accepted: July 4, 2005

Accepted by: Anne S. Tsui 